\title{
トマトジュースの商業的無菌性を確保する加熱殺菌条件の検討
}

\author{
長田 隆 ${ }^{1,3, \dagger}$, 中野千紗 ${ }^{2}$, 大坪研一 ${ }^{3}$ \\ ${ }^{1}$ トーアス株式会社, ${ }^{2}$ カゴメ株式会社, ${ }^{3}$ 新潟大学大学院自然科学研究科
}

\section{Heat Sterilization Conditions to Ensure Commercial Sterility of Hot-Filling Tomato Juice}

\author{
Takashi OSADA $^{1,3, \dagger}$, Chisa NAKANO ${ }^{2}$, Kenichi OHTSUBO $^{3}$ \\ ${ }^{1}$ Toasu Corporation, 58 Miyanotsubo, Oosakicho, Toyokawashi, Aiti 442-8516, Japan \\ ${ }^{2}$ Kagome Corporation, 17 Nishitomiyama, Nasushiobara, Tochigi 329-2762, Japan \\ ${ }^{3}$ Graduate School of Science and Technology, Niigata University, 2-8050 Ikarashi, Niigata, Niigata 950-2181, Japan
}

In the production of hot-filling tomato juice products, which $\mathrm{pH}$ value are below 4.6 and distributed at normal temperature, the heat sterilization condition is setting at $121^{\circ} \mathrm{C}$ for 0.7 min with Bacillus coagulans as an indicator, and it is widely used throughout the world. This study covered the three studies, 1) investigate bacterial spore contamination level of raw tomato material, 2) discover the best heat sterilization indicator, and 3) set the heat sterilization conditions in order to determine the ensured commercial sterility. In the production of hot-filling tomato juice products, which $\mathrm{pH}$ value are below 4.6, B. coagulans is unlikely to cause deterioration. Tainted tomatoes are often contaminated by Bacillus subtilis group and Genus Thermoanaerobacterium. In this repot, spores of Genus Thermoanaerobacterium, which is identified from spoiled tomato juice and have been known to cause deterioration, should be used as a heat sterilization indicator for hot-filling tomato juice products. We used the heat resistance of hot-filling tomato juice ( $\mathrm{pH}$ 4.6) with Genus Thermoanaerobacterium as an indicator. The required heat treatment conditions for proper sterilization were a $D_{121^{\circ} \mathrm{C}}{ }^{-v a l u e}$ of $0.3 \mathrm{~min}$, a $z$-value of $8.2^{\circ} \mathrm{C}$, and an $\mathrm{F}_{121^{\circ} \mathrm{C}}$-value of $1.5 \mathrm{~min}$ (D value $\left.\times 5\right)$. As a result of the above findings, the current heat sterilization conditions with $121^{\circ} \mathrm{C}$ for $0.7 \mathrm{~min}$ are not sufficient for proper sterilization.

Keywords: tomato juice, commercial sterility, Bacillus, Thermoanaerobacterium, spore

1. 緒言

トマトジュース缶詰は 1923 年マクニール\&リビー社 が商品化し，1929年ころから米国内で普及したが, 1931 年に, 最初のフラットサワー型変敗が発生し，缶 詰業者に多くの経済的損失をもたらした [1]. その後, 1947 年に Sognefeatら [2] がトマトジュースの加熱殺 菌条件 $\left(121^{\circ} \mathrm{C} \cdot 42\right.$ 秒間) を, 1950 年に Becker and Pederson ら [3] が変敗原因菌種をBacillus coagulans であると報告し，現在まで世界に広く普及している．

我々は，これまで国産トマトジュース缶詰に扔いて，

(受付 2015 年 1 月 6 日, 受理 2015 年 3 月 13 日)

${ }^{1} \bar{\uparrow} 442-8516$ 愛知県豊川市大崎町宫の坪 58 番地

${ }^{2} \bar{T} 329-2762$ 栃木県那須塭原市西富士 17 番地

${ }^{3}$ T $950-2181$ 新潟県新潟市五十嵐 2 の町 8050

Fax: 0533-65-9910, E-mail: osada@toasu.co.jp

公益社団法人 日本缶詰びん詰レトルト食品協会

第 63 回技術大会 (新潟) 発表論文
フラットサワー変敗とは異なる膨張変敗をしばしば経 験して打り，トマトジュースの加熱殺菌条件ついて， 再検討する必要があると考えた。そこで変敗したトマ トジュース缶詰の原因菌種を調べClostridium 属や Thermoanaerobacterium 属であったこと，また，変敗 したトマトジュースの $\mathrm{pH}$ は 4.4 以上であったこと [4]. さらに，原料トマトにおける細菌芽胞污染状況を調べ, 高頻度に分離されたのは, Bacillus subtilis group や Clostridium butyricumであり，B. coagulans は分離さ れなかったこと [5] を報告した。

全国清涼飲料工業会によれば，健康志向を背景に 2012 年のトマトジュースの生産量は, 急激に拡大し $77,600 \mathrm{kl}$ （前年比 $179 \%$ ）であった. 2013 年は 76,900 kl（前年比 $99 \%$ ）とほぼ横ばいであった。 なお，トマ トジュースには，シーズンパックと濃縮還元の 2 種類 の製法がある。前者はトマトを収穫後加工工場で搾汁 しジュースにするタイプであり，後者はペーストにし 
た後希釈してジュースにするタイプである。いずれの 製法もトマトジュースにはJAS 規格上食塩以外の添加 が認められて打らず，酸味料を添加し酸度調整はでき ないため，トマトジュースの $\mathrm{pH}$ はトマト原料の $\mathrm{pH}$ に 左右される。近年では，JASへのリコピン規格追加で より完熟した原料を使用したトマトジュースの製造が されていることや，消費者の嗜好変化を背景に，甘く 酸味の少ないトマト原料を使用したトマトジュースの 商品開発が行われているなど，トマトジュースの $\mathrm{pH}$ 上昇による微生物的安全性の低下が懸念される状況で ある。

本研究は，今後ますます需要が高まる常温流通する トマトジュースについて，微生物的安全性の向上のた め，加熱殺菌指標菌であるB. coagulans の妥当性を評 価し，適切な加熱殺菌指標菌の選定と商業的無菌性が 確保された加熱殺菌条件を算出することを目的とした。

具体的には，原料として用いられる国産や海外産原 料トマトの細菌芽胞污染を調べ，その污染状況を把握 するとともに，殺菌指標菌としてのB. coagulansの妥 当性を評価し，過去に変敗事例があるThermoanaerobacterium 属を指標に，商業的無菌性を確保するための 加熱殺菌条件を算出した。 なお，国産原料については 著者ら [5] の報告があるため，ここでは海外産の原料卜 マトの細菌芽胞污染状況と, 国産原料については試作 したトマトジュース中に打けるB. coagulansの污染状 況を調べた.

\section{2. 実 験 方 法}

\section{1 試料および試料の調製}

\subsection{1 トマト原料}

1）海外産トマト原料

海外産卜マト原料は，ジュース原料であるペースト を用いた。主な輸入先であるトルコ，イタリア，スペ イン，北米，中国の 5 ヶ国と今後輸入量が増加すると考 えられるオーストラリア，インドの 2 ヶ国の計 7 ヶ国 9 サプライヤーより，2012，2013 年の 2 年間に製造され たものから，各年の $4 \sim 6$ 試料を，ただし，インドにつ いては 2013 年のみを使用した。なお，ペーストは 300 $\mathrm{g} \sim 2 \mathrm{~kg}$ 無菌バックに採取されたものを常温輸送した.

2）国産トマト原料による PET ボトル詰トマトジュー スの試作と恒温試験

栃木県那須塩原地方で収穫したトマト約 $6,000 \mathrm{~kg}$ を, 収穫後，常温で試験室へ運搬し，洗浄，加熱搾汁およ び $25 \%$ 水酸化ナトリウム溶液で， $\mathrm{pH} 4.4$ および 4.6 に なるように調整した後， $108 \pm 2{ }^{\circ} \mathrm{C} \cdot 60$ 秒間の加熱殺菌

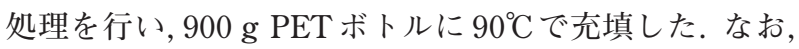
同ボトルの製造本数は $\mathrm{pH} 4.4$ が 3240 本, pH 4.6 が 3288 本であった.

\subsection{2 培地の調製}

本研究に用いた培地を以下に示す。なお，4)～6) は 駒木ら [6] の方法で調製した.

1) 標準寒天培地

日水製薬社製を用い，常法により調製した。

2) デキストローストリプトンアガー (以下, DTA と略す)

バクトトリプトン (Difco 社製) $10 \mathrm{~g}$, グルコース $5 \mathrm{~g}$, 寒天 $20 \mathrm{~g}$, 脱イオン水 $1 \mathrm{~L}$ を加え, 加温溶解し, $\mathrm{pH} 7.3$ 〜 7.5 に調整後，ブロムクレゾールパープル $0.004 \mathrm{~g}$ を 加え， $121^{\circ} \mathrm{C} ， 20$ 分間高圧殺菌した。

3）変法 TGC 寒天培地（以下， mTGC と略す）

日水製薬社製を用い，常法により調製した。ただし， 市販品は寒天が $0.7 \mathrm{~g} / \mathrm{L}$ であるため，2\%になるように 添加した。

4） PE-2 培地（以下, PE-2 と略す） [6]

5) ピーインフュージョン半流動培地扎よび寒天培地 (以

下，PIS，PIA と略す） [6]

6） $\mathrm{GC}$ ブロス A 培地（以下， GCA と略す）[6]

\section{2 原料トマトの細菌芽胞数, 分離と同定}

\subsection{1 原料トマトの細菌芽胞数とトマトジュースか らの細菌の分離}

1）海外産トマト原料の細菌芽胞数

（1）好気性細菌芽胞数

前記 2.1.1のトマトペーストを滅菌したポリエチレン 袋に $25 \mathrm{~g}$ 採取し, 滅菌脱イオン水 $75 \mathrm{~mL}$ 加え, 良く混

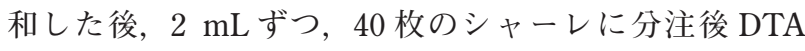
に混釈し, 20 枚は $35^{\circ} \mathrm{C}$, 残りは $55^{\circ} \mathrm{C} て ゙ 3 \sim 5$ 日間培養し, 形成した集落数を数え，トマトペースト $10 \mathrm{~g}$ 中の中温 および高温細菌芽胞数とした。

（2）嫌気性ガス産生菌芽胞数

前記 2.1.1のトマトペーストを $0.1 \mathrm{~g}, 1 \mathrm{~g}$ 扎よび $10 \mathrm{~g}$ を，それぞれ PE-2（トマトペーストに対し 10～20 倍量） 10 本に分注した。 このうち 5 本は $35^{\circ} \mathrm{C}$, 残りは $55^{\circ} \mathrm{C} て ゙$ 3〜5 日間培養し, ガス発生の有無を確認し, 最確数表（5 管法）より，トマトペースト $10 \mathrm{~g}$ 中の中温打よび高温 細菌芽胞数とした。

2）国産原料トマトで試作したPET ホトトル詰トマト ジュースからの細菌分離

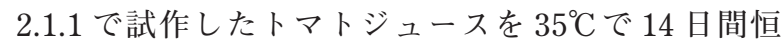
温放置した後，全試料から $1 \mathrm{~mL}$ を標準寒天培地に混釈 し， $35^{\circ} \mathrm{C} て ゙ 7$ 日間培養した。各平板培地に形成した集 落を全て分離した。

\subsection{2 細菌の分離}

分離された菌株は, 好気性細菌種は標準寒天培地, 嫌気性細菌種は PE-2 と mTGC へ植え継ぎ純粋分離し た。なお，分離菌株が多数の場合は，集落の形態が異 なるものを選抜した。 


\subsection{3 分離株の同定}

分離株の同定は，PCR 法により 16SrRNAの遺伝子を 解析し, データベースと照合した.

DNA は Prepman Ultra Reagent (ライフテクノロジー ズ社製）を用い,プロトコールに従って操作した。なお， 抽出した DNAの 16SrRNAの塩基配列領域は, ユニバー サルプライマー $(27 \mathrm{f}, \mathrm{r} 1 \mathrm{~L})$ を用い, $\mathrm{PCR}$ 反応 $95^{\circ} \mathrm{C} て ゙$ 1 分, $50^{\circ} \mathrm{C}$ で 1 分, $72^{\circ} \mathrm{C}$ で 1.5 分, 35 サイクルで増幅し, 得られた PCR 産物を MinElute PCR Purification Kit (キ アゲン社製) によって精製した。

塩基配列は Big Dye Terminator v3.1 Cycle Sequencing Kit（ライフテクノロジーズ社製）によりシークエンス 反応を行った. 反応条件は $95^{\circ} \mathrm{C}$ で 10 秒， $50^{\circ} \mathrm{C}$ で 5 秒, $60^{\circ} \mathrm{C}$ で 4 分， 25 サイクルで増幅し，得られたシークエ ンス反応物を Centri-Sep Spin columns（ライフテク） ロジーズ社製）により精製した。塩基配列はDNA シー ケンサーABI-3130（ライフテクノロジーズ社製）を用 いて決定した．決定した塩基配列を NCBI BLASTによ り相同検索し，相同性 $99 \%$ 以上は種，99\%未満は属ま でとした。

\section{3 供試菌株芽胞の各 $\mathbf{p H}$ に調整したトマトジュー ス中での発育}

\subsection{1 供試菌株}

カゴメ (株) 保存の Thermoanaerobacterium 属 3 株 (菌 株番号 PH1，FDA3，FDA6)，Thermoanaerobacterium thermosaccharolyticum 1 株（菌株番号 20）の計 4 株を 用いた。これら 4 菌株はいずれもトマト缶詰の膨張変 敗品から分離し同定した菌株である.

\subsection{2 供試菌株の芽胞調製}

供試菌株 4 株の保存芽胞液 $0.5 \mathrm{~mL}$ を PE-2 に接種し, 沸騰水中 10 分加熱処理した後， $55^{\circ} \mathrm{C}$ で培養した。 ガス 産生による発育がみられたら，GCAに $1 \mathrm{~mL}$ 接種し， 嫌気的（アネロパック角型ジャー 三菱ガス化学社製） に $55^{\circ} \mathrm{C}, 5$ 日間培養した。培養液を滅菌ガーゼでろ過し， ろ液を洗浄のため 3 回遠心分離 $\left(6^{\circ} \mathrm{C}, 3,000 \mathrm{rpm}, 10\right.$ 分間）したものを滅菌バイアルに移し，試験までー $30^{\circ} \mathrm{C}$ で保存した。

\subsection{3 芽胞数の測定}

上記 2.3.2で調製した芽胞液 $1 \mathrm{~mL}$ をPIA によるアナ エロビック・パウチ法により測定した。なお，芽胞の 活性化の加熱処理条件は，沸騰水中，10 分間とし，培 養条件は $55^{\circ} \mathrm{C} ， 5$ 日間とした。

\subsection{4 供試菌株芽胞のトマトジュース中での発育}

各 $\mathrm{pH}$ に調整したトマトジュース中に打ける供試菌株 の発育を測定した。

\section{1）トマトジュースの調製}

加熱殺菌したトマトジュース（カゴメブランド， ト マト $100 \%$ ストレート，160 $\mathrm{g}$ 缶）を $\mathrm{pH} 4.3 ， 4.4 ， 4.5$
および 4.6 になるように $3 \mathrm{~N}$ 水酸化ナトリウム溶液を加 え，耐熱ネジロビン $(100 \mathrm{~mL}$ 容 $)$ に $80 \mathrm{~mL}$ 分注し，こ れを $105^{\circ} \mathrm{C}$ で 5 分間高圧殺菌した。

なお，用いたトマトジュースの $\mathrm{pH}$ は 4.32 であった。

2) トマトジュース中に打ける発育

（1）芽胞液の接種

供試菌株の芽胞液を滅菌脱イオン水で希釈し，各 $\mathrm{pH}$ に調整したトマトジュースにそれぞれ芽胞数が約 $10^{3} \mathrm{CFU} / \mathrm{mL}$ になるように加え，硬質ガラス管（内径 $7 \mathrm{~mm}$ ，外径 $9 \mathrm{~mm}$ ，長さ $15 \mathrm{~cm}$ ：以下チューブとする) 13 本に $3 \mathrm{~mL}$ ずつ分注し，菌を接種しないトマトジュー スも，それぞれ 9 本に $3 \mathrm{~mL}$ ずつ分注し，酸素炎で溶封 した. これらを沸騰水中で，10 分加熱処理した.

（2）初発芽胞数， pH の測定

加熱処理後の無接種試料と芽胞液接種試料の各 3 本 について測定した．芽胞数の測定は, 2.3 .3 と同様に行っ た。なお，残りの液を使用し $\mathrm{pH}$ 計（東和電波工業製 HM-50V) で pH を測定した.

(3) 恒温放置打よび発育判定

加熱処理後の無接種試料 6 本，芽胞液接種試料 10 本 を，55 ${ }^{\circ} \mathrm{C} ， 30$ 日間恒温放置し，外観および $\mathrm{pH}$ の変化 が認められたものを発育陽性とした。

\section{4 供試菌株芽胞のトマトジュースでの耐熱性}

1）菌株の選定

供試菌株の中から，最も耐熱性が強い株を選定した。

供試菌株の芽胞液を滅菌脱イオン水で希釈し，芽胞 数が約 $10^{5} \mathrm{CFU} / \mathrm{mL}$ になるようにPISに加え，チュー ブに $2 \mathrm{~mL}$ ずつ分注後，酸素炎で溶封した。これらを恒 温油槽（タイテック社製：サーモバ $\mathrm{OH}-16$ ，油は日本 油脂社製：ポリエチレングリコール 400）で，所定の条 件で加熱処理した後， $55^{\circ} \mathrm{C} ， 14$ 日間培養し，外観の変 化により発育陽性とした。このとき，1 加熱温度・時間 条件にチューブ 1 本を供した。

2）０.067 M リン酸緩衝液（pH 7.0）に打ける而熱性

供試菌株の芽胞液 $1 \mathrm{~mL}$ を，0.067 $\mathrm{M}$ リン酸緩衝液 （pH 7.0）に芽胞数が約 $10^{5} \mathrm{CFU} / \mathrm{mL}$ になるように加え， チューブに $2 \mathrm{~mL}$ ずつ分注し酸素炎で溶封した。これら を恒温油槽で, 所定の条件で加熱処理後, PIAによる アナエロビック・パウチ法により測定した。このとき， 1 加熱温度・時間条件にチューブ 1 本を供した。

3）トマトジュース（pH 4.6）中に打ける耐熱性

供試菌株の芽胞液 $1 \mathrm{~mL}$ をトマトジュース（pH 4.6） に芽胞数が約 $10^{5} \mathrm{CFU} / \mathrm{mL}$ になるように加え，チュー ブに $3 \mathrm{~mL}$ ずつ分注し酸素炎で溶封した。チューブは 恒温油槽を用い, 所定の条件で加熱処理した。このとき， 1 加熱温度・時間条件にチューブ 5 本を供した。また， 培養条件は $55^{\circ} \mathrm{C} ， 30$ 日間とし，外観打よび $\mathrm{pH}$ の変化 により発育の有無を判定した。 
なお，加熱処理時間の補正は，松田ら [7] の補正表よ り，加熱処理時間から 1.5 分を減じた.

\section{3. 結果および考察}

\section{1 原料トマトの細菌芽胞污染}

\section{1 .1 海外産トマトペーストの細菌芽胞数および分 離菌の同定}

供試試料の細菌芽胞数およびその種について調べた 結果を，Table 1 および 2 に示す。

1) 好気性細菌芽胞数

供試 84 検体の $10 \mathrm{~g}$ 当たりの好気性細菌芽胞数は, 中温性で分離されなかったのは 61 検体 $(73 \%), 1 \mathrm{CFU}$ 〜 $10 \mathrm{CFU}$ 未満は 9 検体 $(10 \%), 10 \mathrm{CFU} \sim 10^{4} \mathrm{CFU}$ 未満 が 14 検体 $(17 \%)$ で，高温性で分離されなかったのは 65 検体 $(77 \%), 1 \mathrm{CFU} \sim 10 \mathrm{CFU}$ 未満は 11 検体（13\%） および $10 \mathrm{CFU} \sim 10^{2} \mathrm{CFU}$ 未満が 7 検体（8\%）であった. 国別では，イタリア産が中温，高温性ともに多く，イ ンド産は中温性の污染が比較的高かった。

\section{2）嫌気性ガス産生菌芽胞数}

供試 84 検体の $10 \mathrm{~g}$ 当たりの嫌気性ガス産生菌芽胞 数は，中温性で 0.2 未満が 70 検体 $(83 \%)$ で，0.2〜 未満が 7 検体 $(8 \%), 1 \sim 10^{2}$ 未満が 7 検体 $(8 \%)$ であつ た。また，高温性は 0.2 未満が 42 検体 $(50 \%) ， 0.2 \sim 1$ 未満が 23 検体 $(27 \%) ， 1 １ 0$ 未満が 15 検体 (18\%) および $10 \sim 10^{2}$ 未満が 3 検体 $(4 \%)$ であった. 国別では， イタリア産が中温，高温性ともに多く，オーストラリ
ア産は高温性の污染が比較的高かった。

よって，海外 7 力国のトマトペースト 84 検体につい て，10 g 当たりの好気性芽胞抢よび嫌気性ガス産生菌 芽胞の污染状況を調べた結果，好気性芽胞数が 10CFU 未満であったのは中温性が 70 検体 $(83 \%) ，$ 高温性が 76 検体 $(90 \%)$ で，また，嫌気性ガス産生菌芽胞数が 1 未満であったのは中温性が 77 検体 $(92 \%)$ ，高温性が 65 検体（77\%）であった.

3）分離菌株の同定結果

海外産トマトペーストから分離した好気性の菌株 82 株の同定結果は，中温菌種はBacillus が 21 株, Paenibacillus が 26 株, Brevibacillus が 1 株であり，B. amyloliquefaciens, P. azoreducens が多かった. 高温菌種 は Bacillus が 12 株，Geobacillus が 9 株，Paenibacillus が 6 株, Tuberibacillus が 5 株, Brevibacillus が 2 株であった。 な抢，国産卜マト同様，トマトジュースの殺菌指標菌で あるB. coagulans は分離されなかった。一方，嫌気的に 分離した菌株 34 株の同定結果は，中温菌種は Clostridium と，Thermoanaerobacterium が同様に 2 株，高温菌種は 30 株全て Thermoanaerobacterium であり，T. aciditolerans が 10 株，T. aotearoense が 9 株，T. thermosaccharolyticum が 3 株の順であった．山口ら [9] は，変敗缶詰食品から 分離した Thermoanaerobacterium thermosaccharolyticum, T. aotearoense および T. aciditolerans の 3 種の耐熱性は 同様であり，殺菌試験などの指標菌選定には種による区 別が不要であると報告している．このことから 3 群を 1 群として扱うと，海外のトマトペーストにはいずれの国

Table 1 The number of heat resistant bacterial spores in tomato paste produced in seven different countries.

\begin{tabular}{|c|c|c|c|c|c|c|c|c|c|c|c|c|c|c|c|c|c|c|}
\hline \multirow[b]{3}{*}{$\begin{array}{c}\text { Country } \\
\text { of manufacture }\end{array}$} & \multirow[b]{3}{*}{$\begin{array}{c}\text { Number } \\
\text { of samples } \\
\text { examined }\end{array}$} & \multirow[b]{3}{*}{$\begin{array}{c}\mathrm{pH} \\
\text { range }\end{array}$} & \multicolumn{8}{|c|}{ Heat resistant aerobic spore $(\mathrm{CFU} / 10 \mathrm{~g})^{1)}$} & \multicolumn{8}{|c|}{ Heat resistant anaerobic spore $(/ 10 \mathrm{~g})^{2)}$} \\
\hline & & & \multicolumn{5}{|c|}{ Mesophilic } & \multicolumn{3}{|c|}{ Thermophilic } & \multicolumn{4}{|c|}{ Mesophilic } & \multicolumn{4}{|c|}{ Thermophilic } \\
\hline & & & $\begin{array}{l}\overrightarrow{0} \\
\vec{Z} \\
\text { l } \\
0 \\
0\end{array}$ & $\begin{array}{l}\text { ?을 } \\
\text { V } \\
\text { ?े } \\
\text { vै }\end{array}$ & $\begin{array}{l}\text { vo } \\
\text { V } \\
\text { ? } \\
0\end{array}$ & $\begin{array}{l}\stackrel{ }{\mathrm{V}} \\
\text { l } \\
-1\end{array}$ & 0 & \begin{tabular}{l}
0 \\
\multirow{2}{*}{} \\
V \\
$?$ \\
0
\end{tabular} & $\begin{array}{l}\stackrel{0}{V} \\
\text { v } \\
-1\end{array}$ & $\circ$ & $\begin{array}{l}\text { vo } \\
\text { V } \\
\text { ? } \\
\text { o् }\end{array}$ & $\begin{array}{l}\stackrel{O}{V} \\
\text { ? } \\
\text { - }\end{array}$ & $\begin{array}{l}\vec{V} \\
\vdots \\
\sim \\
0\end{array}$ & $\stackrel{\sim}{\stackrel{\nabla}{V}}$ & 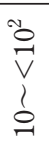 & $\begin{array}{l}\stackrel{0}{1} \\
\text { v } \\
\text { I }\end{array}$ & 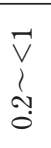 & $\stackrel{v}{\grave{v}}$ \\
\hline Turkey & 21 & $\begin{array}{l}4.23 \\
-4.30\end{array}$ & & & & $3^{3)}$ & 18 & & 1 & 20 & & & & 21 & & 1 & 4 & 15 \\
\hline Italy & 10 & $\begin{array}{l}4.25 \\
-4.41\end{array}$ & & 6 & 4 & & & 5 & 4 & & 2 & 4 & & 4 & 2 & 4 & 1 & 3 \\
\hline Spain & 10 & $\begin{array}{l}4.25 \\
-4.32\end{array}$ & & & & & 10 & & & 10 & & & & 10 & & 3 & 3 & 4 \\
\hline China & 20 & $\begin{array}{l}4.17 \\
-4.22\end{array}$ & & & & 2 & 18 & 2 & & 18 & & & 1 & 19 & & & 5 & 15 \\
\hline America & 8 & $\begin{array}{l}4.22 \\
-4.39\end{array}$ & & & 1 & 3 & 4 & & 4 & 4 & & & 3 & 5 & & 2 & 6 & \\
\hline Australia & 10 & $\begin{array}{l}4.31 \\
-4.37\end{array}$ & & & & & 10 & & 2 & 8 & & 1 & 2 & 7 & 1 & 5 & 3 & 1 \\
\hline India & 5 & $\begin{array}{l}4.21 \\
-4.34\end{array}$ & 1 & 2 & & 1 & 1 & & & 5 & & & 1 & 4 & & & 1 & 4 \\
\hline Total & 84 & & 1 & 8 & 5 & 9 & 61 & 7 & 11 & 65 & 2 & 5 & 7 & 70 & 3 & 15 & 23 & 42 \\
\hline
\end{tabular}

1) The number of bacterial spores by aerobic plate method using DTA medium (CFU/10 g)

2) The number of bacterial spores by MPN method using PE-2 medium $(/ 10 \mathrm{~g})$

3) Number of samples 
Table 2 Microflora isolated from tomato paste made in seven different countries.

\begin{tabular}{|c|c|c|c|c|c|c|}
\hline \multicolumn{4}{|c|}{ Aerobic bacterial } & \multicolumn{3}{|c|}{ Anaerobic bacterial } \\
\hline Mesophilic & & Thermophilic & & Mesophilic & & Thermophilic \\
\hline $\begin{array}{c}\text { Species/ } \\
\text { (Isolated strains) }\end{array}$ & & $\begin{array}{c}\text { Species/ } \\
\text { (Isolated strains) }\end{array}$ & & $\begin{array}{c}\text { Species/ } \\
\text { (Isolated strains) }\end{array}$ & & $\begin{array}{c}\text { Species/ } \\
\text { (Isolated strains) }\end{array}$ \\
\hline Bacillus & & Bacillus & & Clostridium & & hermoanaerobacterium \\
\hline amyloliquefaciens & (7) & smithii & (5) & nitrophenolicum & (1) & saccharolyticum \\
\hline cereus & (4) & gelatini & (3) & aciditolerans & (1) & aotearoense \\
\hline licheniformis & (4) & shackletonii & (2) & Thermoanaerobacterium & & aciditolerans \\
\hline aerius & (2) & licheniformis & (2) & aciditolerans & (2) & thermosaccharolyticum (3) \\
\hline fumarioli & (1) & Geobacillus & & & & $s p$ \\
\hline megaterium & (1) & kaustophilus & (5) & & & \\
\hline sonorensis & (1) & thermoleovorans & (4) & & & \\
\hline$s p$ & (1) & Paenibacillus & & & & \\
\hline Paenibacillus & & cookie & (4) & & & \\
\hline azoreducens & (14) & phoenicis & (1) & & & \\
\hline cookie & (3) & $s p$ & (1) & & & \\
\hline konsidensis & (2) & Brevibacillus & & & & \\
\hline dendritifomis & (1) & borstelensis & (1) & & & \\
\hline phoenicis & (1) & $s p$ & (1) & & & \\
\hline$s p$ & (5) & Tuberibacillus & & & & \\
\hline $\begin{array}{l}\text { Brevibacillus } \\
\quad \text { choshinensis }\end{array}$ & (1) & $s p$ & (5) & & & \\
\hline
\end{tabular}

のものからも比較的高頻度に分離されており, トマト ジュースの変敗防止対策には Thermoanaerobacterium 芽 胞の少ない原料を受入れ使用することが重要と考える. すなわち, PE-2 培地 5 本にトマトペースト $10 \mathrm{~g}$ ずつ接 種し， $55^{\circ} \mathrm{C} て ゙ 5$ 日間培養後，ガス発生がない原料を選定 することである。

\subsection{2 国産原料トマトで試作した PET ボトル詰トマ} トジュースからの細菌分離

1）好気性中温細菌芽胞数

国産原料トマトで試作したPET ホトル詰トマト ジュースを $35^{\circ} \mathrm{C}, 2$ 週間恒温放置した後, $\mathrm{pH} 4.4$ は 3,240 本の内 16 本, $\mathrm{pH} 4.6$ は 3,288 本の内 2 本, から細菌が 分離された。

\section{2) 分離菌の同定結果}

pH 4.4 の試作トマトジュースより分離された菌種 16 株は全てBacillus amyloliquefaciens で，また, pH 4.6 の試作トマトジュースより分離した 2 菌株は $B$. amyloliquefaciens とBacillus 属であった. 駒木ら [8] は, B. amyloliquefaciens は, B. subtilis, B. licheniformis の 近縁種であり，加熱殺菌の対象としては一群として捉 えるべきと報告している，このことから，過去の報告 [5] 同様にトマト原料の主体污染菌種は，B. subtilis group であった。 また, トマトジュースの殺菌指標菌である $B$. coagulans は分離されなかった。

\subsection{3 殺菌指標菌である B. coagulans の妥当性}

国産トマトでは $6,000 \mathrm{~kg}$ ，海外産トマトペースト 10 $\mathrm{g}$ （トマトジュース $40 \mathrm{~mL}$ 相当）から，B. coagulans 芽 胞は分離されなかった. Rice ら [10] は，トマトジュー スを変敗させる $\mathrm{pH}$ とB. coagulans 芽胞数の関係を調 ベ, $\mathrm{pH} 4.4$ のトマトジュースを変敗させるのに 22 〜 $650 \mathrm{CFU} / \mathrm{mL}$, White[11] は 1 3 CFU/mL が必要であ ると報告している。これより，トマト原料の $B$. coagulans 芽胞の污染度はトマトジュースを変敗させ るリスクは低いと考えられる。実質的には原料污染度 の高いB. subtilis group や Themoanaerobacterium 属 を考えるべきであり，とくに変敗事例のある Themoanaerobacterium 属芽胞をトマトジュースの加熱 殺菌指標として管理するべきである。これまで, Themoanaerobacterium 属芽胞については，耐熱性が強 いため，加熱殺菌で殺滅するのは困難とされ，もっぱ ら製造工程に持ち込まない除菌対応の菌種として取り 扱われており，酸性食品での本菌種芽胞の耐熱性はあ まり調べられてこなかった.

\section{2 供試菌芽胞の各 pHに調整したトマトジュース 中での発育}

供試菌芽胞の各 $\mathrm{pH}$ に調整したトマトジュース中での 発育結果を Table 3 に示す．供試菌株 4 株すべて pH 4.6 で発育し, pH 4.5 では 1 株 (菌株番号 20) が発育したが, pH 4.4 以下では発育がみられなかった。このことから， トマトジュースの $\mathrm{pH} 4.4$ 以下に管理すれば Themoanaerobacterium 属芽胞による変敗を防止するこ とができると考えられる。なお，犬飼ら [12]は， 
Table 3 Growth of selected strains of Thermoanaerobacterium sp in tomato juice at various pH levels.

\begin{tabular}{|c|c|c|c|c|c|c|}
\hline \multirow{4}{*}{ Species } & \multirow{4}{*}{ Strain No. } & \multirow{4}{*}{$\begin{array}{l}\text { Incubation } \\
\left(\text { month } /{ }^{\circ} \mathrm{C}\right)\end{array}$} & \multicolumn{4}{|c|}{$\mathrm{pH}$} \\
\hline & & & $4.3^{1)}$ & 4.4 & 4.5 & 4.6 \\
\hline & & & $4.3^{2)}$ & 4.4 & 4.5 & 4.6 \\
\hline & & & $4.2^{3)}$ & $4.2 \sim 4.3$ & $4.3 \sim 4.4$ & 4.4 \\
\hline Thermoanaerobacterium sp & PH1 & & $-4)$ & - & - & + \\
\hline $\begin{array}{l}\text { Thermoanaerobacterium } \\
\text { thermosaccharolyticum }\end{array}$ & FDA3 & $1 / 55$ & - & - & - & + \\
\hline Thermoanaerobacterium sp & FDA6 & & - & - & - & + \\
\hline Thermoanaerobacterium $s p$ & 20 & & - & - & + & + \\
\hline
\end{tabular}

1) Before sterilization 2) After sterilization 3) After incubation for 1 month at $\left.55^{\circ} \mathrm{C} 4\right)-$, No growth; + , Positive growth

Clostridium 属細菌芽胞の発育に及ぼす pH の影響を培 地中で調べ，C. thermosaccharolyticum は pH 4.73 で 10 株中 5 株に発育がみられ，pH 4.51 では発育しなかった と報告した。このことからも，本種芽胞の発育下限 $\mathrm{pH}$ は4.4〜4.5のあたりと推定させる.

\section{3 供試菌芽胞のトマトジュース中での耐熱性}

供試菌株の中より最も強い耐熱性を有している菌株 を選抜するために，PIS での耐熱性について，加熱温度 $\left(110 ， 115 ， 120\right.$ および $\left.125^{\circ} \mathrm{C}\right)$ で 10,20 および 30 分 間処理し， $\mathrm{D}_{115^{\circ} \mathrm{C}}$ を求めた。菌株番号 PH1 は 1 分未満, FDA3 は 1.9 分, FDA6 は 5.0 分, 20 が最も強く 6.7 分 であった．よって，以下の試験には菌株番号 20 を用い ることとした

\subsubsection{M リン酸緩衝液（pH 7.0）中での耐熱性}

菌株番号 20 の $0.067 \mathrm{M}$ リン酸緩衝液（pH 7.0）にお ける生残曲線を Fig. 1 に示し，加熱致死時間曲線を Fig. 2 に示す.

この結果から菌株番号 20 の $\mathrm{D}_{121}{ }^{\circ} \mathrm{C}$ 值 $\left(121^{\circ} \mathrm{C}\right.$ 加熱時に おける $90 \%$ 致死時間） および $z$ 值（加熱致死時間曲線 の勾配，D 值の 10 倍の変化に対応する温度変化）は, 0.5 分および $6.2^{\circ} \mathrm{C}\left(95 \%\right.$ 信頼限界 $\left.4.6 \sim 9.5^{\circ} \mathrm{C}\right)$ であった.

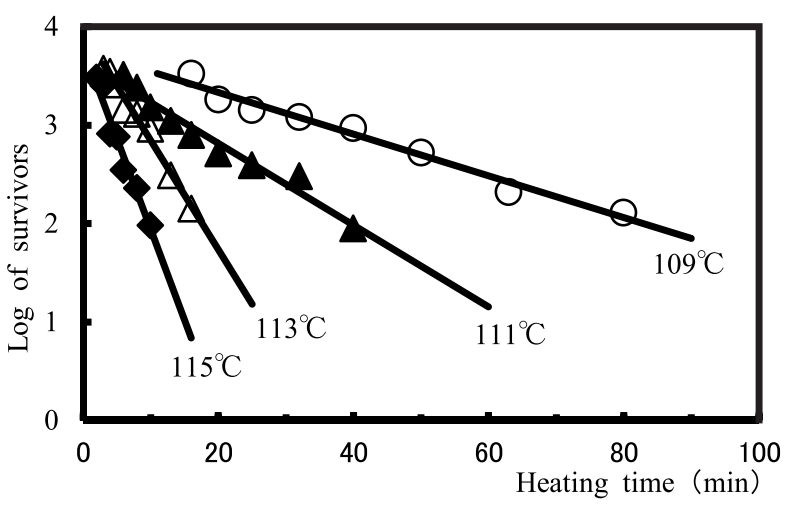

Fig. 1 Survival curves for spores of Thermoanaerobacterium strain No.20 heated in $0.067 \mathrm{M}$-phosphate buffer (pH 7.0).
過去，容器包装詰食品で変敗原因となった本種の $0.067 \mathrm{M}$ リン酸緩衝液での耐熱性については，遠山ら

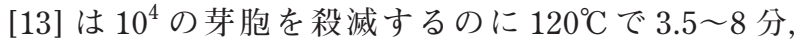
池上ら [14] は $120^{\circ} \mathrm{C}$ で 5 分を要したこと．田中 [15] は

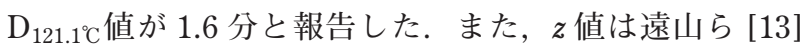
は9.27 9.71 ${ }^{\circ} \mathrm{C}$, 池上ら [14] は $10^{\circ} \mathrm{C}$, 田中 [15] は $10.9^{\circ} \mathrm{C}$ と報告している. よって，菌株番号 20 の $\mathrm{D}_{121^{\circ} \mathrm{C}}$ 值 0.5 分はそれらと比べると約 $1 / 2 \sim 1 / 3$ であった.

\subsection{2 トマトジュース（pH 4.6）中での耐熱性}

菌株番号 20 のトマトジュース（pH 4.6）の加熱温度 $\left(111 \sim 117^{\circ} \mathrm{C}\right)$ に打ける耐熱性測定結果を Table 4 に示 し，次式より各加熱温度の D 值を算出した。得られた $\mathrm{D}$ 值より加熱致死時間曲線を Fig. 3 に示す.

$\mathrm{D}=\mathrm{t} /(\log \mathrm{a}-\log \mathrm{b})$

$(\mathrm{t}=$ 補正後の加熱時間 $\mathrm{a}=$ 初発芽胞数 $\mathrm{b}=$ 加熱時間 $\mathrm{t}$ の ときの生残芽胞数)

上式を使用し， $111^{\circ} \mathrm{C}$ の $\mathrm{D}$ 值を算出する例を以下に示 した.

補正後の加熱時間 $(\mathrm{t}) 25$ 分のとき， $\mathrm{a}=\left(1.4 \times 10^{4}\right)$ $\times 3 \mathrm{~mL} \times 5$ 本 $=2.1 \times 10^{5}, \mathrm{~b}=4$ であり, $\mathrm{D}_{111^{\circ} \mathrm{C}}=25 /(\log (2.1$

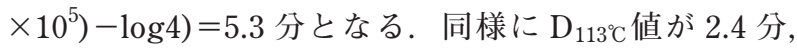

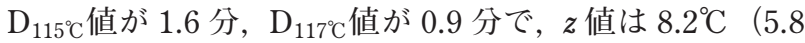

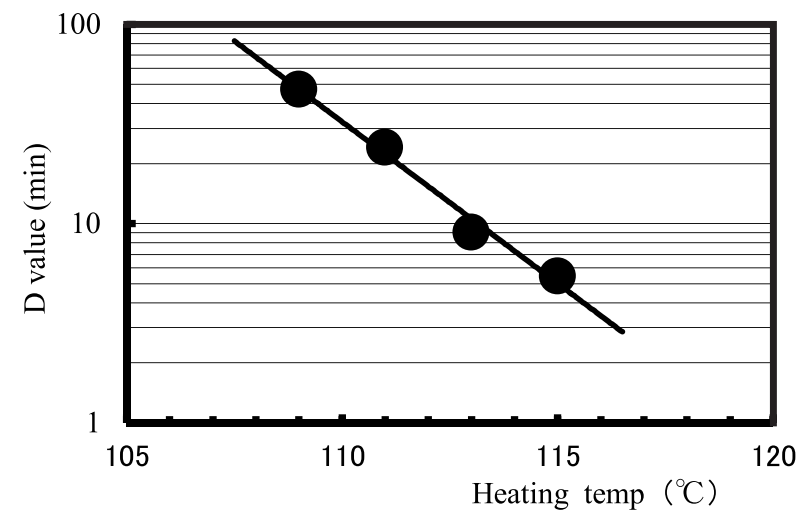

Fig. 2 Thermal death time curves for spores of Thermoanaerobacterium strain No.20 heated in $0.067 \mathrm{M}$-phosphate buffer (pH 7.0). 
Table 4 Heat resistance of Thermoanaerobacterium strain No.20 spores heated and subcultured in tomato juice ( $\mathrm{pH} 4.6)$.

\begin{tabular}{ccccc}
\hline \multirow{2}{*}{$\begin{array}{c}\text { Corrected heating time } \\
(\mathrm{min})\end{array}$} & \multicolumn{5}{c}{ Heating temperature $\left({ }^{\circ} \mathrm{C}\right)$} \\
\cline { 2 - 5 } & 111 & 113 & 115 & 117 \\
\hline 2 & $-{ }^{1)}$ & - & - & $5^{2)}$ \\
3 & - & - & - & 5 \\
4 & - & - & - & 5 \\
5 & - & - & 5 & 1 \\
6 & - & - & 5 & 0 \\
8 & - & - & 2 & 0 \\
10 & - & 5 & 0 & - \\
13 & - & 1 & 0 & - \\
16 & - & 0 & 0 & - \\
20 & 5 & 0 & 0 & - \\
25 & 4 & 0 & - & - \\
32 & 0 & 0 & - & - \\
40 & 0 & 0 & - & - \\
50 & 0 & - & - & - \\
63 & 0 & - & - & - \\
80 & 0 & - & - & - \\
\hline
\end{tabular}

The spores amounting $4.2 \times 10^{4} \mathrm{CFU}$ was incubated to each samples tube, and they were incubated for 1 month at $55^{\circ} \mathrm{C}$ after heating. 1) Not tested 2) Number of positive growth tubes in the five samples examined

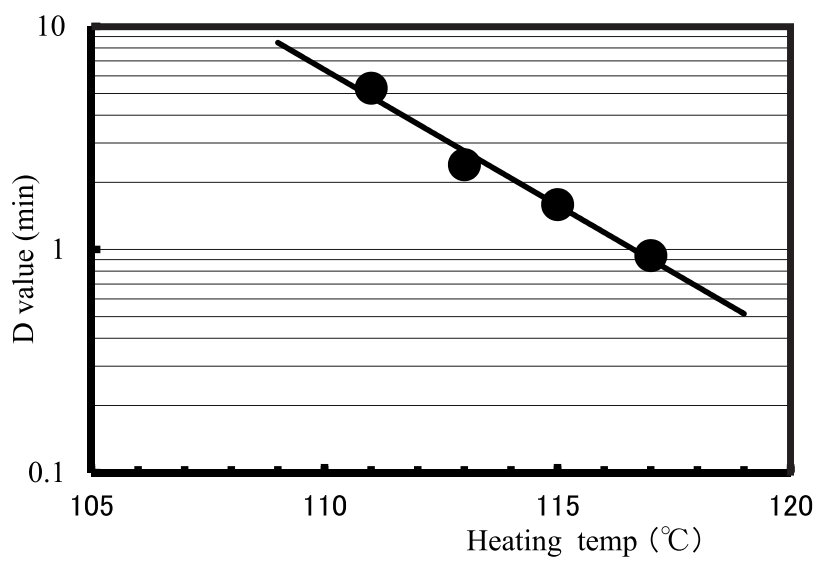

Fig. 3 Thermal death time curves for spores of Thermoanaerobacterium strain No.20 heated in tomato juyce ( $\mathrm{pH} 4.6)$.

〜 $\left.14.2^{\circ} \mathrm{C}\right)$ であった。この結果から $\mathrm{D}_{121^{\circ} \mathrm{C}}$ 值を換算する と, 0.3 分であった.

菌株番号 20 のリン酸緩衝液およびトマトジュースに おける耐熱性值を Table 5 に示す。リン酸緩衝液がトマ トジュースより約 2 倍の耐熱性を示していた.
以上のことから，トマト原料から B. coagulans は分 離されず，トマトジュースの変敗原因である Thermoanaerobacterium 属が高い頻度で分離されたこ とから，常温流通する $\mathrm{pH} 4.6$ 未満のトマトジュースの 加熱殺菌の指標菌は, B. coagulansよりも Thermoanaerobacterium 属にすべきである。また，加 熱殺菌条件は，一般的には $\mathrm{D}_{121}{ }^{\circ} \mathrm{C}$ 值の 5 倍とし算出する ことから $121^{\circ} \mathrm{C}$ における殺菌值は 1.5 分であった. 現在, トマトジュースの加熱殺菌条件として採用されている $121^{\circ} \mathrm{C} ， 0.7$ 分と比較すると不足していた.

$121^{\circ} \mathrm{C} ， 1.5$ 分の加熱殺菌処理がトマトジュースの品 質に及ぼす影響については，確認はできていないが， 品質低下が十分予想される. 今後の検討として, pH 4.4 以下のトマトジュースであれば Thermoanaerobacterium 属芽胞は発育しないことから，トマトジュースの $\mathrm{pH}$ 管理を強化し，加熱殺菌条件をより緩和する研究が 必要である.

\section{4. 結論}

常温流通する $\mathrm{pH} 4.6$ 未満のトマトジュースの製造に 扣いて, 原料トマトの細菌芽胞污染状況を調べ, 現在, 加熱殺菌の指標として広く用いられているB. coagulans の妥当性について評価し，商業的無菌性を確保する加 熱殺菌条件を算出した。

1）国産トマト原料約 $6,000 \mathrm{~kg}$ を使用し試作したトマト ジュースの好気性中温細菌では，B. amyloliquefaciens が 17/18 株分離され，B. subtilis group が污染菌の主体 であり，B. coagulans は分離されなかった.

2）海外卜マト原料（トマトペースト $10 \mathrm{~g}$ ）の污染細菌種 では，好気性中温菌は B. subtilis group や Paenibacillus $s p$, 高温菌は Geobacillus sp, Bacillus sp, Paenibacillus $s p$ が多く分離されたが，B. coagulans は分離されなかっ た。嫌気性菌では，幅広くThermoanaerobacterium 属 が分離された。

3） Thermoanaerobacterium 属は，供試菌株 4 株の中で 菌株番号 20 だけが pH 4.5 のトマトジュースで発育し た。しかし，pH 4.4 以下では発育しなかった。

4) Thermoanaerobacterium属菌株番号 20 のマト ジュース（pH 4.6）での $\mathrm{D}_{121}{ }^{\circ} \mathrm{C}$ 值は 0.3 分， $z$ 值は $8.2^{\circ} \mathrm{C}$ $\left(95 \%\right.$ 信頼限界は $\left.5.8 \sim 14.2^{\circ} \mathrm{C}\right)$ であった。これより，

Table 5 K Parametric value of heat resistance for Thermoanaerobacterium strain No.20 spores suspended in 0.067-M phosphate buffer ( $\mathrm{pH} 7.0)$ and tomato juice $(\mathrm{pH} 4.6)$.

\begin{tabular}{ccccc}
\hline Heating medium & \multicolumn{3}{c}{ D value $(\mathrm{min})$} & \multicolumn{2}{c}{$\begin{array}{c}z \text { value } \\
\left({ }^{\circ} \mathrm{C}\right)\end{array}$} \\
\cline { 2 - 4 } & $115^{\circ} \mathrm{C}$ & $120^{\circ} \mathrm{C}$ & $121^{\circ} \mathrm{C}$ & $6.2(4.6 \sim 9.5)^{1)}$ \\
0.067-M Phosphate buffer $(\mathrm{pH} 7.0)$ & 5.0 & 0.8 & 0.5 & \\
Tomato juice $(\mathrm{pH} \mathrm{4.6)}$ & 1.6 & 0.4 & 0.3 & $8.2(5.8 \sim 14.2)$ \\
\hline
\end{tabular}

1) $(95 \%$ confidentials $)$ 


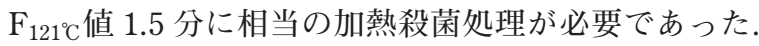
以上のことから，トマトジュースを製造する上では, 原料由来のB. coagulans による変敗の危害性は低く, 実質的には原料污染度の高い, B. subtilis group や Themoanaerobacterium 属を考えるべきであり，とくに 変敗事例のある Themoanaerobacterium 属芽胞をトマト ジュースの加熱殺菌指標として管理するべきである. しかしながら，現在，トマトジュースの加熱殺菌条件

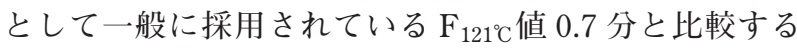
と不足していた。

\section{謝辞}

本研究をまとめるにあたり，ご助言を賜りました公 益社団法人日本缶詰びん詰レトルト食品協会 駒木勝 氏 大久保良子氏に深く感謝いたします。

\section{引用 文 献}

1) W. A. Gould; "Tomato Production, Processing and Technology” Third Edition, 1992, p.420.

2) R. Sognefest, J. M. Jackson.; Presterilization of canned tomato juice Food Technol, 1 78-84 (1947).

3) E. M. Becker, C. S. Pederson; The physiological characters of Bcillus coagulans (Bacillus thermoacidurans). J. Bacteriol. 59, 717-725 (1950).

4) T. Osada; "Thermal resistant spore forming bacteria isolated from spoiled canned tomato juice manufactured by the of fresh-squeezed packing” (in Japanese). The Kanzume Jiho. 88, 727-732 (2009).

5) T. Osada, M. Takei; "Contamination by heat resistant bacterial spores during manufacturing process of fresh-squeezed canned tomato juice” (in Japanese). The Kanzume Jiho, 88, 733-743 (2009).

6) M. Komaki, R. Ichikawa, N. Matsuda; "Sporulation medium for Clostridium thermosaccharolyticum" (in Japanese). The Kanzume Jiho, 70, 990-997 (1991).

7) N. Matsuda, M. Komaki, K. Matsunawa; "Heating and cooling lag correction in heat treatment for determination of heat resistance of bacterial spores" (in Japanese). The Kanzume Jiho, 59, 785 -790 (1980).

8) M. Komaki; "ATARASHII RETORTOSHOKUHIN KAIHATSU·SEIZOU HANDOBUKKU” (in Japanese); M. Yokoyama, K. Tanaka, Science Forum, 2007, pp.229-236.
9) T. Yamaguchi; Japan canned Association, 57 times technology convention program, p.11 (2008).

10) A. C. Rice, C. S. Pederson; "Factors influencing growth of Bacillus coagulanss in canned tomato juice. 1.Size of inoculum and oxygen conentration”Food Res. 19, 115-123 (1954).

11) L. S. White; Spoilage bacteria in tomato product. Food Res. 16, 442-428 (1951).

12) S. Inukai, M. Kimura, M. Hisatomi; "Effect of $\mathrm{pH}$, Sodium chloride and sucrose on heat risistance of spores of Clostridium thermosacchariolyticum and Clostridium sporogenes" (in Japanese ). The Kanzume Jiho, 70, 998-1008 (1991).

13) Y. Toyama, Z. Nakajima; "Studies on the thermophilic bacteria causing 'swells' of canned food. (2) Some characters that have relation to production of canned food" (in Japanese). J. Fish Dis, 16, 60-64 (1950).

14) Y. Ikegami, D. Mori; "Studies on canned bamboo shoots -V. Spoilage bacteria on bamboo shoots packed in large cans" (in Japanese). Report of Toyo institute of Food Technology, 11, 170-174 (1974).

15) S. Tanaka; "Bacteriological studies on the spoilage of canned baby clem, (1). The physiological characteristics of isolated organisms of the sulphide and gaseous spoilage and results of the experimental packs" (in Japanese). The Kanzume Jiho, 70, 998-1008 (1991).

要旨

常温流通する $\mathrm{pH} 4.6$ 未満のトマトジュースの製造に 打いて，B.coagulans を指標に $121^{\circ} \mathrm{C} ， 0.7$ 分の加熱殺 菌条件が世界で広く採用されている。本研究は原料卜 マトの細菌芽胞污染を調べ，適切な指標菌を検討し， 商業的無菌性を確保する加熱殺菌条件の算出を行った。

$\mathrm{pH} 4.6$ 未満のトマトジュースを製造する上では, B.coagulans による変敗の危害性は低く，原料污染度の 高い, B.subtilis group や Themoanaerobacterium 属が 重要で，とくに変敗事例のある Themoanaerobacterium 属芽胞をトマトジュースの加熱殺菌指標に管理するべ きと結論した。本属芽胞を指標菌に，トマトジュース (pH 4.6) に扔ける耐熱性を測定した結果, $\mathrm{D}_{121{ }^{\circ} \mathrm{C}}$ 值は 0.3 分, $z$ 值は $8.2^{\circ} \mathrm{C}$ で, これらの值から殺菌值を算出すると,

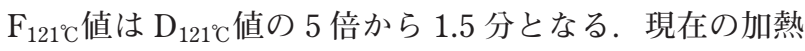
殺菌条件は，これを下回っている. 